4. Aslan D. Addition of oral iron to plasma transfusion in human congenital hypotransferrinemia: a 10-year observational follow-up with the effects on hematological parameters and growth. Pediatr Blood Cancer 2018;65:e26789.

5. Li H, Ginzburg YZ. Crosstalk between iron metabolism and erythropoiesis. Adv Hematol 2010;2010:605435.

6. Trombini P, Coliva T, Nemeth E, Mariani R, Ganz T, Biondi A, Piperno A. Effects of plasma transfusion on hepcidin production in human congenital hypotransferrinemia. Haematologica 2007;92:1407-1410.
7. Nemeth E, Ganz T. Hepcidin and iron-loading anemias. Haematologica 2006;91:727-732.

8. Bartnikas TB, Andrews NC, Fleming MD. Transferrin is a major determinant of hepcidin expression in hypotransferrinemic mice. Blood 2011;117:630-637.

9. Coffey R, Ganz T. Erythroferrone: An erythroid regulator of hepcidin and iron metabolism. Hemasphere 2018;2:e35.

10. Boshuizen $M$, van der Ploeg $K$, von Bonsdorff $L$, Biemond BJ, Zeerleder SS, van Bruggen $R$, Juffermans NP. Therapeutic use of transferrin to modulate anemia and conditions of iron toxicity. Blood Rev 2017;31:400-405.

\title{
Immune-Mediated Thrombotic Thrombocytopenic Purpura after BNT162b2 Vaccine
}

\author{
BNT162b2 Aşısı Sonrası Gelişen Immün Aracılı Trombotik Trombositopenik Purpura
}

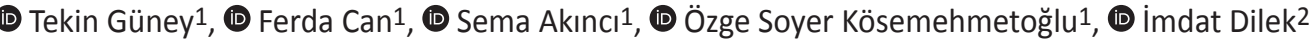 \\ 1 University of Health Sciences Turkey, Ankara City Hospital, Clinic of Hematology, Ankara, Turkey \\ 2 Yıldırım Beyazıt University, Ankara City Hospital, Clinic of Hematology, Ankara, Turkey
}

\section{To the Editor,}

Immune-mediated thrombotic thrombocytopenic purpura (iTTP) is a rare but life-threatening condition characterized by microvascular thrombosis [1]. The roles of several vaccines have been described in its etiology $[2,3]$. With the coronavirus disease-19 (COVID-19) pandemic, various vaccines have been developed. As a result of vaccine studies, the BNT162b2 (BioNTech) vaccine was approved by the US Food and Drug Administration in August 2021. The first case of iTTP following administration of BNT162b2 was reported around the same time [4].

A 48-year-old female patient was admitted to the hematology outpatient clinic on June 26 with complaints of weakness, nausea, dizziness, and bruising. There was no positive finding in her history, except that she had received the first dose of the BNT162b2 vaccine on June 14,2021 . She was taking no medications. She stated that ecchymoses had developed from the third day after vaccination. On admission, hemoglobin was $10.7 \mathrm{~g} / \mathrm{dL}$, platelet count was $88 \times 10^{9} / \mathrm{L}$, creatinine level was $0.5 \mathrm{mg} / \mathrm{dL}$, lactate dehydrogenase (LDH) level was $515 \mathrm{U} / \mathrm{L}$, reticulocyte count was $231 \times 10^{9} / \mathrm{L}$, Coombs tests were negative, and a peripheral smear showed polychromasia and normoblasts with schistocytes.
Prothrombin and activated partial thromboplastin times were normal, the PLASMIC score was 6 with a high risk for ADAMTS13 (a disintegrin and metalloproteinase with a thrombospondin type 1 motif, member 13) deficiency, and a polymerase chain reaction testing for SARS-CoV-2 was negative. ADAMTS13 enzyme activity was dramatically reduced to $<0.2 \%$ with a high antibody titer level of $>90 \mathrm{U} / \mathrm{mL}$. Antiplatelet factor 4 testing cannot be performed in our center. As the patient was diagnosed with iTP, methylprednisolone treatment at $1 \mathrm{mg} / \mathrm{kg} /$ day with one daily volume of therapeutic plasma exchange (TPE) was started. After 10 sessions of TPE, the patient had not responded (platelets $80 \times 10^{9} / \mathrm{L}, \mathrm{LDH} 368 \mathrm{U} / \mathrm{L}$ ), and rituximab was added at $375 \mathrm{mg} / \mathrm{m}^{2}$ once a week. After a total of 4 doses of rituximab, hemoglobin was $11.1 \mathrm{~g} / \mathrm{dL}$, thrombocyte count was $323 \times 10^{\circ} / \mathrm{L}$, and LDH was $472 \mathrm{U} / \mathrm{L}$. ADAMTS13 activity was $0.2 \%$ with a persistently high antibody level of $50 \mathrm{U} /$ $\mathrm{mL}$ one month after the last dose of rituximab. Additional immunosuppressive treatment was planned. Although COVID-19 vaccines have been in use for a limited period of time and there are still unknowns in the score calculation, the Naranjo Adverse Drug Reaction Probability Score was calculated as 6, meaning that the reaction was a probable adverse reaction. 
In early-phase studies, heparin-induced thrombocytopenia with thrombosis, thrombosis in unusual locations, and thrombotic microangiopathy cases were reported after administration of viral vector-based COVID-19 vaccines such as ChAdOx1 nCoV-19 and Ad26.COV2.S [5,6]. Antibodies against platelet factor 4 have also been clearly defined [7]. However, the pathogenesis of COVID-19 vaccine-associated iTTP is currently unclear. Despite its rarity, disease activation was reported in patients with a previous history of iTTP in early-phase studies with the BNT162b2 mRNA vaccine $[8,9,10]$. Like in our case, the median time to disease diagnosis after vaccination was found to be 14 days on average in most of those cases. Responses were achieved with TPE, corticosteroids, rituximab, and caplacizumab. Unfortunately, since we do not have access to caplacizumab in our country, we could not use caplacizumab for our patient. So far, few cases of iTTP have been reported after mRNA-mediated vaccination. As a result, we wanted to draw attention to this rare and potentially fatal condition that can be encountered after mRNA-based vaccination against COVID-19. It is generally difficult to control such cases solely with TPE, and one or more lines of immunosuppressive therapy with or without caplacizumab are required in some cases.

Keywords: COVID-19 vaccine, Thrombotic thrombocytopenic purpura, BNT162b2

Anahtar Sözcükler: COVID-19 aşı, Trombotik trombositopenik purpura, BNT162b2

\section{Informed Consent: Obtained.}

\section{Authorship Contributions}

Concept: T.G., F.C., S.A., Ö.S.K., I.D.; Design: T.G., F.C., S.A., Ö.S.K., I.D.; Data Collection or Processing: T.G., F.C., S.A., Ö.S.K., I.D.; Analysis or Interpretation: T.G., F.C., S.A., Ö.S.K., I.D.; Literature Search: T.G., F.C., S.A., Ö.S.K., I.D.; Writing: T.G., F.C., S.A., Ö.S.K., i.D.

Conflict of Interest: No conflict of interest was declared by the authors.
Financial Disclosure: The authors declared that this study received no financial support.

\section{References}

1. Scully $M$, Hunt BJ, Benjamin $S$, Liesner R, Rose P, Peyvandi F, Cheung B, Machin SJ; British Committee for Standards in Haematology. Guidelines on the diagnosis and management of thrombotic thrombocytopenic purpura and other thrombotic microangiopathies. Br J Haematol 2012;158:323-335.

2. Kadikoylu G, Yavasoglu I, Bolaman Z. Rabies vaccine-associated thrombotic thrombocytopenic purpura. Transfus Med 2014;24:428-429.

3. Dias PJ, Gopal S. Refractory thrombotic thrombocytopenic purpura following influenza vaccination. Anaesthesia 2009;64:444-446.

4. de Bruijn S, Maes MB, De Waele L, Vanhoorelbeke K, Gadisseur A. First report of a de novo iTTP episode associated with an mRNA-based anti-COVID-19 vaccination. J Thromb Haemost 2021;19:2014-2018.

5. Thaler J, Ay C, Gleixner KV, Hauswirth AW, Cacioppo F, Grafeneder J, Quehenberger $P$, Pabinger I, Knöbl P. Successful treatment of vaccineinduced prothrombotic immune thrombocytopenia (VIPIT). J Thromb Haemost 2021;19:1819-1822.

6. Greinacher A, Thiele T, Warkentin TE, Weisser K, Kyrle PA, Eichinger S. Thrombotic thrombocytopenia after ChAdOx $1 \mathrm{nCov}-19$ vaccination. N Engl J Med 2021;384:2092-2101.

7. Althaus $K$, Möller $P$, Uzun $G$, Singh $A$, Beck $A$, Bettag $M$, Bösmüller $H$, Guthoff $M$, Dorn F, Petzold GC, Henkes $H$, Heyne $N$, Jumaa $H$, Kreiser $K$, Limpach C, Luz B, Maschke M, Müller JA, Münch J, Nagel S, Pötzsch B, Müller J, Schlegel C, Viardot A, Bäzner $H$, Wolf M, Pelzl L, Warm V, Willinek WA, Steiner J, Schneiderhan-Marra N, Vollherbst D, Sachs UJ, Fend F, Bakchoul T. Antibody-mediated procoagulant platelets in SARS-CoV-2-vaccination associated immune thrombotic thrombocytopenia. Haematologica 2021;106:2170-2179.

8. Sissa C, Al-Khaffaf A, Frattini F, Gaiardoni R, Mimiola E, Montorsi P, Melara B, Amato $M$, Peyvandi F, Franchini M. Relapse of thrombotic thrombocytopenic purpura after COVID-19 vaccine. Transfus Apher Sci 2021;60:103145.

9. Waqar SHB, Khan AA, Memon S. Thrombotic thrombocytopenic purpura: a new menace after COVID BNT162b2 vaccine. Int J Hematol 2021;114:626629.

10. Maayan H, Kirgner I, Gutwein O, Herzog-Tzarfati K, Rahimi-Levene N, Koren-Michowitz M, Blickstein D. Acquired thrombotic thrombocytopenic purpura: a rare disease associated with BNT162b2 vaccine. J Thromb Haemost 2021;19:2314-2317. 